\title{
Development \& Application of Column-Field-Welding Robot
}

\author{
Kiwamu Nisita, \\ Motoaki Itou, Satoshi Miyaki \\ Building dept. Maeda Corporation Tokyo Japan \\ E-mail;nisitak@jcity.maeda.co.jp
}

\begin{abstract}
Column-field-welding robots are generally used in disarranged circumstance of the building site and have to be transferred horizontally and/or vertically within the site. Column-to-column welding joints are full penetration single bevel grooves, which require a high level of welding techniques and need an operation software with huge data. Under these strict conditions, welding works by the robots should be considered as " a manmachine system" which means the cooperation of man and robot. In consequence, it is important, on one hand, to develop welding robot on both software and hardware, on the other hand, to improve circumstance for welding robots to create high degree of efficiency. As a result, high quality at lower cost will be realized.

Key words; column-field-welding robot, full penetration single bevel grooves, man-machine system
\end{abstract}

\section{INTRODUCTION}

Shop-welding robots have been already lined as main production tools in the automobile industry. And recently the employment of welding robots is increasing in the small factories of the steel fabricators. But the development of field-welding robots is very much behind that of shop-welding robots, because the field-welding robot that is a precision machine must be employed in disarranged circumstance of the building site, and column-tocolumn welding joints are full penetration single bevel grooves and require a high level of welding techniques together with operation software with huge data. Those robots have to be transferred horizontally and/or vertically, assembling or disassembling works of welding machines, wires and hoses are required at every work. The time of those works is a primary factor to shorten arcing-time ratio, which indicates an efficiency of welding work.

This development of welding robot in our company has started 1992 and 1\#, 2\#, advanced-2\#, $3 \#$ were made, which were applied to cold-formed square tube columns, welded box-section columns, and circular tubular columns.

This paper describes details of this development from $1 \#$ to $3 \#$, present conditions on the welding capacity, the operationship and the steel flame quality, and future development of the welding robot.

\section{DEVELOPMENT PRINCIPLE}

Main principles on the development of field welding robot are as follows.
(1)Field welding work is cooperation of man and robot

(2)To minimize welding shrinkage, a pair of robots runs symmetrically on the same rail.

(3) One operator operates more than one set.

\section{DEVELOPMENT TRANSITION}

Fig.1 shows the changes of welding robots from 1\# to $3 \#$, and Table 1 shows those specifications.

\section{ROBOT WELDING PROCESS}

Robot welding process is defined below and a flow of welding work is shown in Fig.2.

(1) Groove Shape Check

At first, groove shape is checked by the weldingscale to see if the robot is applicable. If the groove shape is out of the specification, all layers are welded by semi-auto welding or the first layer is welded by semi-auto welding, and the rest is done by robot.

(2) Preparation Works

Robots are set on the rail after the rail is fixed to 4 rail brackets that are fixed to angle pieces welded to column in the factory.

Power cables and control cables, shield gas hoses and cooling water hoses are connected to the equipment as showed in Fig.1.

And windshields are set up around robots.

(3) Welding Works

A type and thickness of column are input into the teaching box that is a terminal controller for the operation of welding robot. 


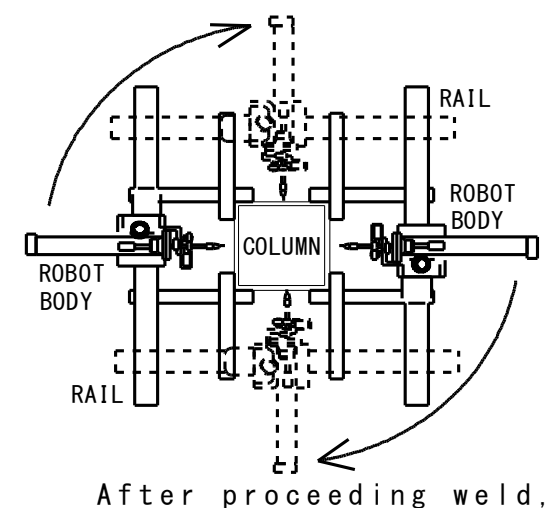

robots on rail are moved.

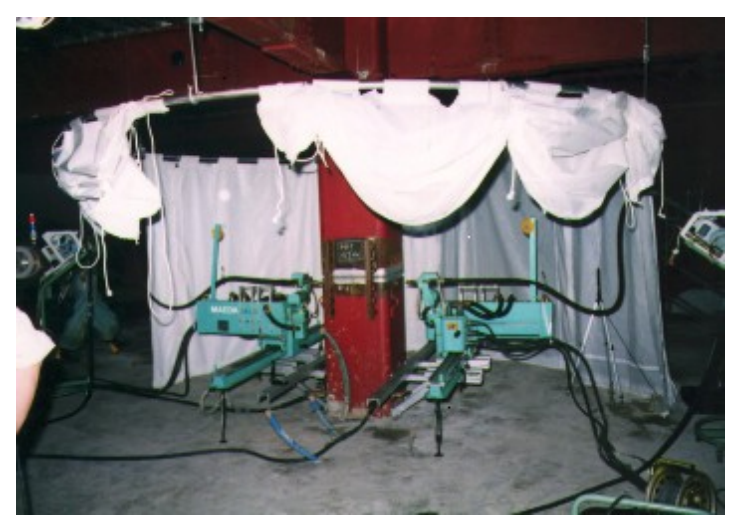

No.1 Robot
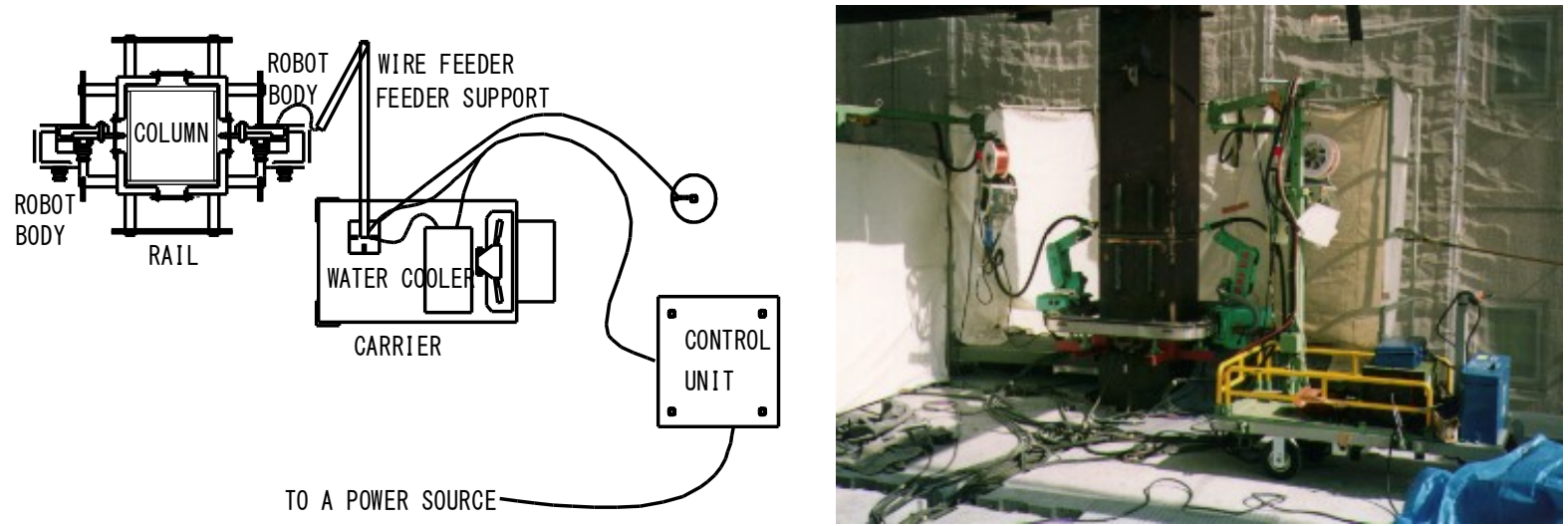

No.2 Robot
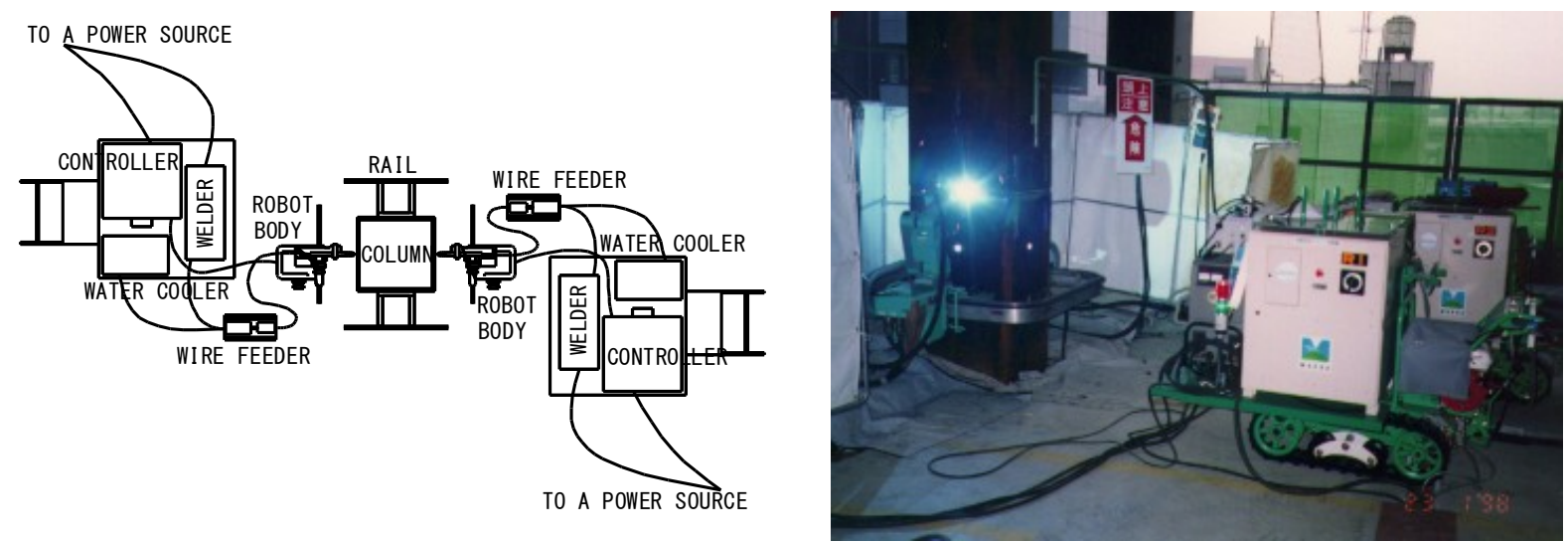

Advanced No.2 Robot

No.3 Robot

Fig.1 Changes of Welding Robots

Table 1 Transition of welding robot

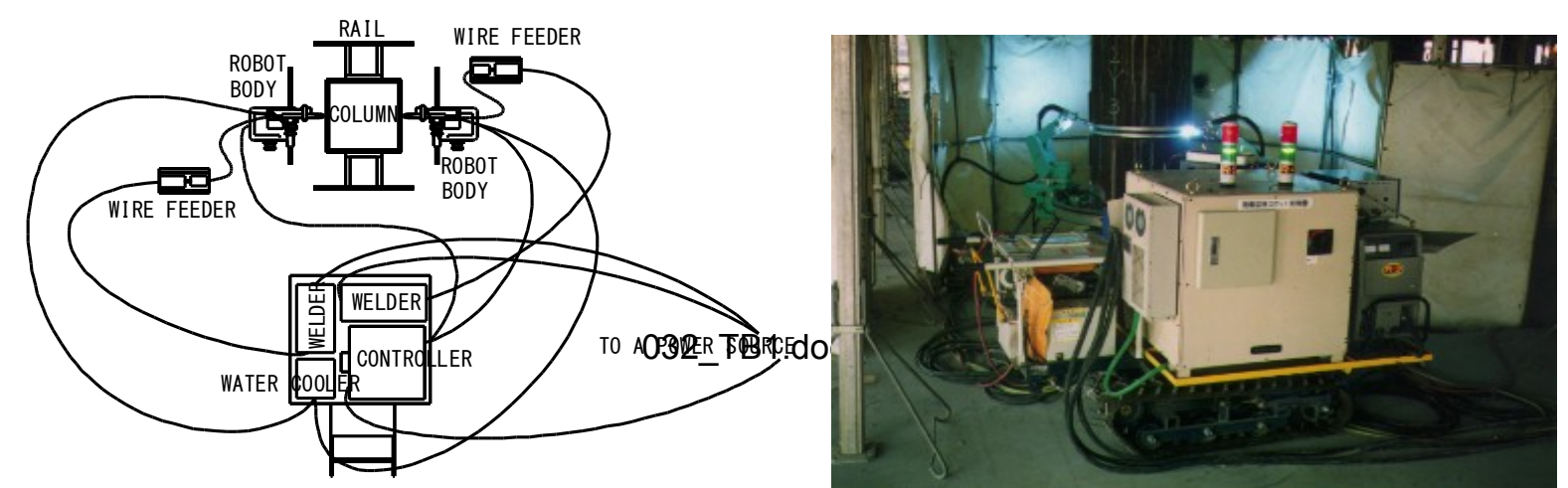




\begin{tabular}{|c|c|c|c|c|}
\hline Item & No.1 (1\#) & No.2 (2\#) & Advanced No.2 (Ad2\#) & No.3 (3\#) \\
\hline Application & $\begin{array}{l}\text { WBC } \\
\text { CSTC }\end{array}$ & $\begin{array}{l}\text { WBC } \\
\text { CSTC } \\
\text { CTC }\end{array}$ & $\begin{array}{l}\text { WBC } \\
\text { CSTC } \\
\text { CTC }\end{array}$ & $\begin{array}{l}\text { WBC } \\
\text { CSTC } \\
\text { CTC }\end{array}$ \\
\hline Size of column & $\begin{array}{l}\text { WBS ; } \square 500 \sim \square 900 \\
\mathrm{CST} ; \square 500 \sim \square 900\end{array}$ & $\begin{array}{l}\text { WBS ; } \square 500 \sim \square 800 \\
\mathrm{CST} ; \square 500 \sim \square 800 \\
\mathrm{CTC} ; \varphi 500 \sim \varphi 800\end{array}$ & $\begin{array}{l}\text { WBS } ; \square 500 \sim \square 800 \\
\text { CST ; } \square 500 \sim \square 800 \\
\text { CTC } ; \varphi 500 \sim \varphi 800\end{array}$ & 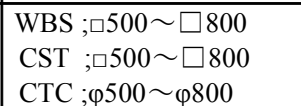 \\
\hline Thickness & $\begin{array}{l}\text { WBS } ; 19 \mathrm{~mm} \sim 50 \mathrm{~mm} \\
\mathrm{CST} ; 19 \mathrm{~mm} \sim 50 \mathrm{~mm}\end{array}$ & $\begin{array}{l}\text { WBS ;19mm } \sim 50 \mathrm{~mm} \\
\text { CST } ; 19 \mathrm{~mm} \sim 36 \mathrm{~mm} \\
\text { CTC } ; 19 \mathrm{~mm} \sim 50 \mathrm{~mm}\end{array}$ & $\begin{array}{l}\text { WBS } ; 19 \mathrm{~mm} \sim 80 \mathrm{~mm} \\
\mathrm{CST} ; 19 \mathrm{~mm} \sim 36 \mathrm{~mm} \\
\mathrm{CTC} ; 19 \mathrm{~mm} \sim 50 \mathrm{~mm}\end{array}$ & $\begin{array}{l}\text { WBS } ; 19 \mathrm{~mm} \sim 80 \mathrm{~mm} \\
\mathrm{CST} ; 19 \mathrm{~mm} \sim 36 \mathrm{~mm} \\
\mathrm{CTC} ; 19 \mathrm{~mm} \sim 80 \mathrm{~mm}\end{array}$ \\
\hline Groove Angle & $35^{\circ} \pm 0.5^{\circ}$ & $\begin{array}{l}35^{\circ} \pm 0.5^{\circ} \mathrm{t}>40 \mathrm{~mm} \\
35^{\circ} \pm 1.0^{\circ} \mathrm{t} \leqq 40 \mathrm{~mm}\end{array}$ & $\begin{array}{l}35^{\circ} \pm 0.5^{\circ} \mathrm{t}>40 \mathrm{~mm} \\
35^{\circ} \pm 1.0^{\circ} \mathrm{t} \leqq 40 \mathrm{~mm}\end{array}$ & $\begin{array}{l}35^{\circ} \pm 0.5^{\circ} \mathrm{t}>40 \mathrm{~mm} \\
35^{\circ} \pm 1.0^{\circ} \mathrm{t} \leqq 40 \mathrm{~mm}\end{array}$ \\
\hline Type & 5 axes Articulated type & axes Articulated type & 5 axes Articulated type & 5 axes Articulated type \\
\hline Welding Voltage & $15 \sim 42 \mathrm{~V}$ & $16 \sim 42 \mathrm{~V}$ & $16 \sim 42 \mathrm{~V}$ & $16 \sim 42 \mathrm{~V}$ \\
\hline Welding Current & $60 \sim 500 \mathrm{~A}$ & $50 \sim 500 \mathrm{~A}$ & $50 \sim 500 \mathrm{~A}$ & $50 \sim 500 \mathrm{~A}$ \\
\hline Welding Speed & $1 \sim 100 \mathrm{~cm} / \mathrm{min}$ & $1 \sim 100 \mathrm{~cm} / \mathrm{min}$ & $1 \sim 100 \mathrm{~cm} / \mathrm{min}$ & $1 \sim 100 \mathrm{~cm} / \mathrm{min}$ \\
\hline Weaving & Automatic Generator & Automatic Generator & Automatic Generator & Automatic Generator \\
\hline Root Gap & $8 \sim 12 \mathrm{~mm}$ & $7 \sim 12 \mathrm{~mm}$ & $7 \sim 12 \mathrm{~mm}$ & $4 \sim 16 \mathrm{~mm}$ \\
\hline Root Gap Difference & $0 \sim 3 \mathrm{~mm}$ & $0 \sim 3 \mathrm{~mm}$ & $0 \sim 3 \mathrm{~mm}$ & $0 \sim 3 \mathrm{~mm}$ \\
\hline Sensing & Laser Sensing & Wire Touch Sensing & Wire Touch Sensing & Wire Touch Sensing \\
\hline Shielding Gas & $\mathrm{C} 02, \operatorname{Ar}(80 \%)+\mathrm{C} 02(20 \%)$ & $\mathrm{C} 02, \operatorname{Ar}(80 \%)+\mathrm{C} 02(20 \%)$ & $\mathrm{C} 02, \operatorname{Ar}(80 \%)+\mathrm{C} 02(20 \%)$ & $\mathrm{C} 02, \operatorname{Ar}(80 \%)+\mathrm{C} 02(20 \%)$ \\
\hline
\end{tabular}

WBC; Welded Box-section Column, CSTC; Cold-formed Square Tube Column, CTC; Circular Tubular Column

A groove shape and a size of column are measured by a wire touch sensing system, and welding starts. After the initial layer, slag is removed at every one layer in case of shield gas $\mathrm{CO} 2$, and at every two layers in case of shield gas $\mathrm{Ar}+\mathrm{CO} 2$. After the middle layers, the surface is checked, and if necessary the surface is repaired by grinder, and welding of final layer starts.

(4) Transfer works are performed in a reverse sequence of the preparation works, and all welding equipment are put on the carriage and this carriage is transferred to next column.

\section{DEVELOPMENT OF ROBOT}

\subsection{Measuring}

Measuring method was changed from laser sensor to wire touch sensor after $2 \#$ robot. This is because that the laser sensor equipment makes errors for a color tone at the groove and an electric noise from robot devices causes greater errors.

Table 2 shows the specifications of the sensor.

For the wire touch sensor, the number of measure points is increased for corners of square tube column.

\subsection{Initial Layer Welding}

First layer welding is difficult for robotic welding as well as manual welding. Main defective factors in the robotic welding are value of current/voltage, aiming point of torch wire, metal temperature of groove, shape of shield bead and gas blow.

Especially blowholes by gas blow occurred much more than another defects. And so a piece of $10 \mathrm{~mm}$ square plates in $1.2 \mathrm{~mm}$ thickness is set under backing to drain gas blow.

\subsection{Root Gap}

To cope with root gap deviation, the tolerance of the robot had been widened, and at the same time, precision of steel frame erection had been enhanced on site.

Table2 Specifications of wire touch sensor

\begin{tabular}{|c|c|}
\hline Control Cycle & 0.1 second \\
\hline Timing of Detection & Touch point \\
\hline Current & $5 \mathrm{Ma}$ \\
\hline Voltage & $300 \mathrm{~V}$ \\
\hline
\end{tabular}

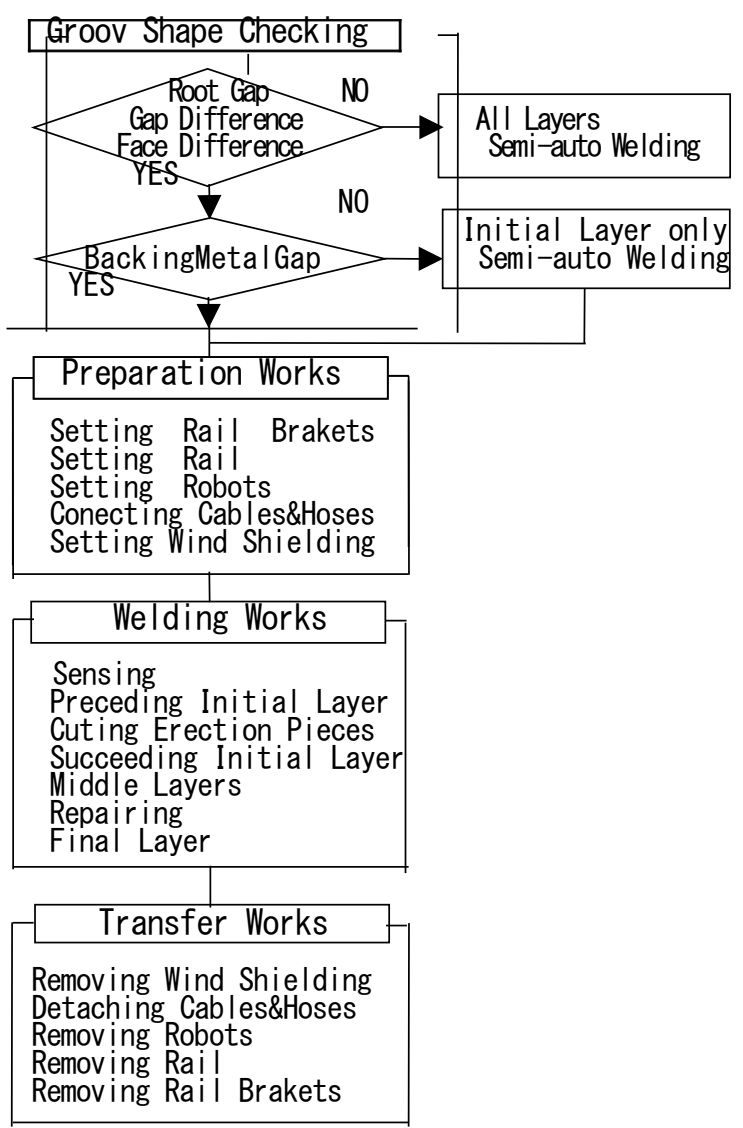


Fig. 2 Welding Process

An excessive deviation of root gap renders a change of layer pattern of the welding necessary, resulting a difference of the number of pass between the two robots. In case of a tubular column, the two robots come into collision with each other because of this excessive deviation. For the $3 \#$ robot, the root gap was enlarged from $7 \sim 12 \mathrm{~mm}$ to $4 \sim 16 \mathrm{~mm}$, and changing a part of soft was made. In addition a preventive function of the collision was devised.

\subsection{Manual Operating}

Semi-auto welding is applied to the additional welding caused by root shape or the repair welding of defects in the appearance of welding. To ease this operation a function of manual operating is added to the robot

\subsection{Cascade(Welding Joint)}

In the sequence of $1 \#$ robot welding, first, the sides with no erection pieces attached are welded from initial layer to the final layer because the rail is straight. Then erection pieces are cut off, robots are shifted right angle together with the rail to weld remaining sides of the column. But those welding joints need to be repaired because most of the defects are concentrated there.

After 2\# robot, to enhance the quality in the cascade, a loop rail is adopted and the welding sequence is changed as follows.

First, the initial layer of the sides with no erection pieces is welded. Second the erection pieces are cut off and the initial layer of another sides is weld. Finally, robots weld all sides from second layer to final layer. Thus repair works of joint surface are much lessened.

Initial Layer
(First)

;Welded joint

Fig.3 Welding Sequence

Fig.3 shows the welding sequence, Fig. 4 shows the detail of layers in the cascade.

\subsection{Robot Equipment}

Equipment of welding robot is composed of a pair of robot-bodies, controllers, welder, teaching box, water-coolers, wire-feeders and a rail.

As shown in Fig 1, the compacting and the downsizing of equipment has been done. As a result in the 3\# robot system, one carriage can carry equipment which used to require two carriages. Since connecting works of cables, hoses and a rail are made to be easy, the time of preparation works and transfer works is shortened.

As welders are put on the carriage, length of secondary cable becomes shorten to $10 \mathrm{~m}$ from $50 \mathrm{~m}$. As a result, weld quality becomes stable with fewer dropouts in voltage.

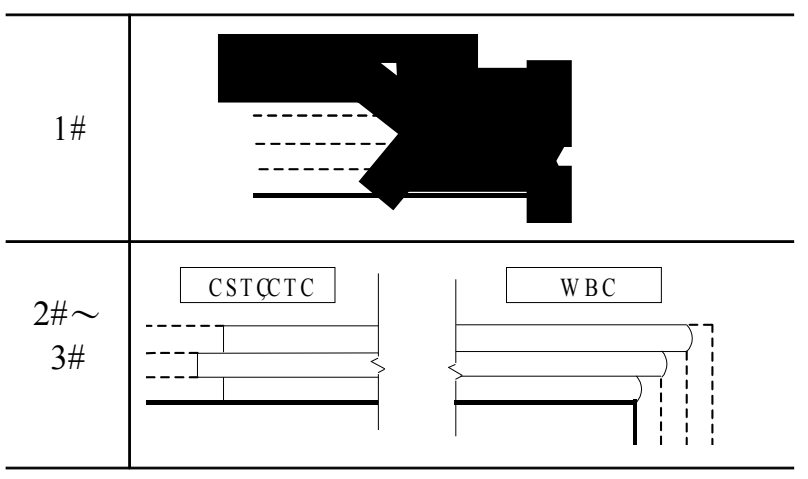

Fig 4 Detail of Layers in Cascade

\section{DEVELOPMENT OF WORK ENVIRONMENT}

\subsection{Steel Work Accuracy}

It is very difficult that the accuracy of all steel works on fabrication and erection is kept within the tolerance of the robot performance. Nevertheless the accuracy of steel works is indispensable condition for welding robot to turn to practical use on site. Consequently, a high precise erection system with an erection regulator and a three-dimension transit has been developed to achieve the accuracy of steel works as required for robot welding.

Fig. 5 shows the high precise erection system. This method needs no wire that hampers welding of robot and transfer of the carriage. Table3 shows design and survey welding length in the case of the ordinary erecting method. Table 4 shows design and survey welding length in the case of the new erecting method

In comparison with the design length, the survey length is $22 \%$ increased in the former, and only $4 \%$ increased in the latter. The result of welding length comparison mentioned above discloses that 
improvement of accuracy of steel columns contributes to a reduction in the welding time and welding cost.

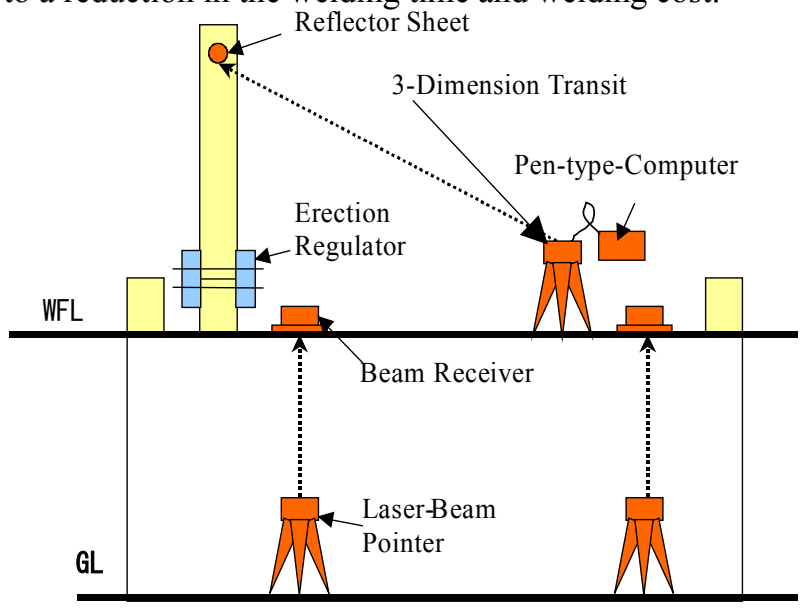

Fig.5 High Precise Erection System

Table3 Welding length by ordinary erecting method

\begin{tabular}{|c|c|c|c|c|c|}
\hline $\begin{array}{c}\text { Column } \\
\text { Mark }\end{array}$ & $\begin{array}{c}\text { Thickness } \\
(\mathrm{mm})\end{array}$ & $\begin{array}{c}\text { Size } \\
(\mathrm{mm})\end{array}$ & $\begin{array}{c}\text { Survey } \\
(\mathrm{m})\end{array}$ & $\begin{array}{c}\text { Design } \\
(\mathrm{m})\end{array}$ & $\begin{array}{c}\text { Survey/ } \\
\text { Design }\end{array}$ \\
\hline 5C7F & 40 & $\square 700$ & 152 & 130 & 1.16 \\
\hline 5C7G & 40 & $\square 700$ & 144 & 130 & 1.10 \\
\hline 5C10G & 40 & $\square 700$ & 140 & 130 & 1.07 \\
\hline 6C7F & 32 & $\square 700$ & 111 & 89.9 & 1.23 \\
\hline 6C6G & 32 & $\square 700$ & 116 & 89.9 & 1.28 \\
\hline 6C7G & 32 & $\square 700$ & 112 & 89.9 & 1.25 \\
\hline 6C8G & 32 & $\square 700$ & 114 & 89.9 & 1.27 \\
\hline 6C9G & 32 & $\square 700$ & 111 & 89.9 & 1.23 \\
\hline 6C10G & 32 & $\square 700$ & 109 & 89.9 & 1.19 \\
\hline 7C6G & 28 & $\square 700$ & 85 & 72.4 & 1.17 \\
\hline 7C7G & 28 & $\square 700$ & 87.7 & 72.4 & 1.21 \\
\hline 7C8G & 28 & $\square 700$ & 87.7 & 72.4 & 1.21 \\
\hline
\end{tabular}

Table4 Welding length by new erecting method

\begin{tabular}{|c|c|c|c|c|c|}
\hline $\begin{array}{c}\text { Column } \\
\text { Mark }\end{array}$ & $\begin{array}{c}\text { Thickness } \\
(\mathrm{mm})\end{array}$ & $\begin{array}{c}\text { Size } \\
(\mathrm{mm})\end{array}$ & $\begin{array}{c}\text { Survey } \\
(\mathrm{m})\end{array}$ & $\begin{array}{c}\text { Design } \\
(\mathrm{m})\end{array}$ & $\begin{array}{c}\text { Survey/ } \\
\text { Design }\end{array}$ \\
\hline 10D & 22 & 0660 & 46.0 & 44.1 & 1.04 \\
\hline 12D & 22 & 0660 & 44.7 & 44.1 & 1.01 \\
\hline 13D & 22 & 0660 & 44.1 & 44.1 & 1.00 \\
\hline 14D & 22 & 0660 & 46.7 & 44.1 & 1.06 \\
\hline 15D & 22 & $\circ 660$ & 46.4 & 44.1 & 1.05 \\
\hline 16D & 22 & $\circ 660$ & 45.6 & 44.1 & 1.03 \\
\hline 18D & 22 & $\circ 660$ & 47.3 & 44.1 & 1.07 \\
\cline { 2 - 5 }
\end{tabular}

\subsection{Rail Bracket}

The accuracy control in the aiming point of torch is important to gain a high quality of the welding, therefore it is required that the errors in the setting rail should be within a tolerance. And it needs a quickness of the setting to shorten the preparation time.

\subsection{Wind-Shield Equipment}

Maximum wind velocity to be allowed for the welding robot is $2 \mathrm{~m} / \mathrm{sec}$. It needs sufficient windshield facility. The setting up of it should be done in a short time, because it is a critical work after setting of welding equipment. Fig.6 shows an example of local windshield device, which is useful for vertical flow of wind.

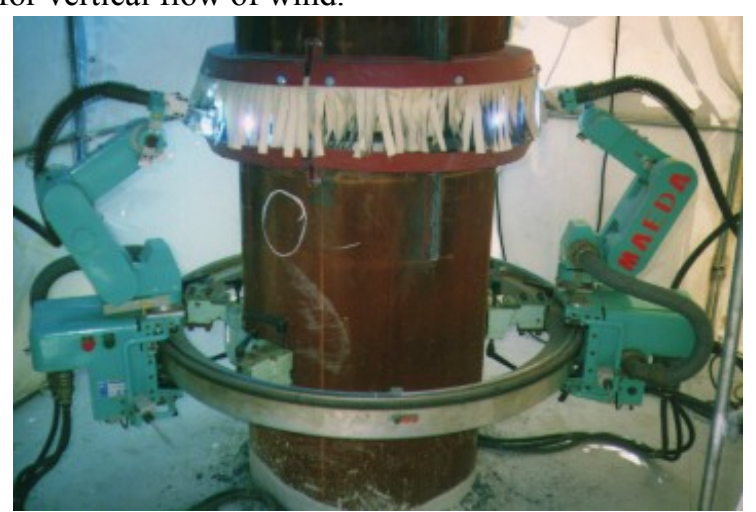

Fig.6 An example of local windshield device

\section{WELDING COST}

Main factors that govern robot-welding cost are the arcing-time ratio and the plate thickness (welding length).

Figure 7 shows the process of preparation works, welding works and transfer works, which are done by two operators with two sets of robots. Fig. 8 shows the composition of these works in comparison with semiauto welding.

Fig. 7 and Fig. 8 indicate that in the robot welding, the increase of the thickness make considerably welding time longer and arcing-time ratio larger. Also these show that the decrease of the preparation time and transfer time makes arcing-time larger and makes it possible to operate three sets of robots by two operators.

Fig.9 shows the decrease ratio of the cost to the thickness of $700 \varphi$ tubular column. This figure shows the present state that the column of thin plate under $32 \mathrm{~mm}$ needs cost-down and consequently the shorten of the preparation-transfer time produces large cost down.

\section{FUTURE SUBJECTS}

\subsection{Operation-ship of Welding robots (1) Teaching}

It is necessary to indicate a trouble shooting method in the teaching box to the operator in order to operate easily welding robots

(2) Detection of Defects

There are many cases that a defect in the robot welding causes another defects continuously.

This needs a function that detects defects and ill shapes under striking arc, and stops directly the robot welding. With this function an operator will be able to operate more than 2 sets of welding robots.

(3) Heat Input Control

Welding robot needs a new function of the heat input control to maintain high quality

(4) Operator License 
Operator license of welding robot falls into a category of a basic class of qualification which is stated in JASS 6(Japan Architectural Standard Specification). Therefore a new operator license is desirable because a quality of robotic welding is greatly dependent upon the skill of operators.

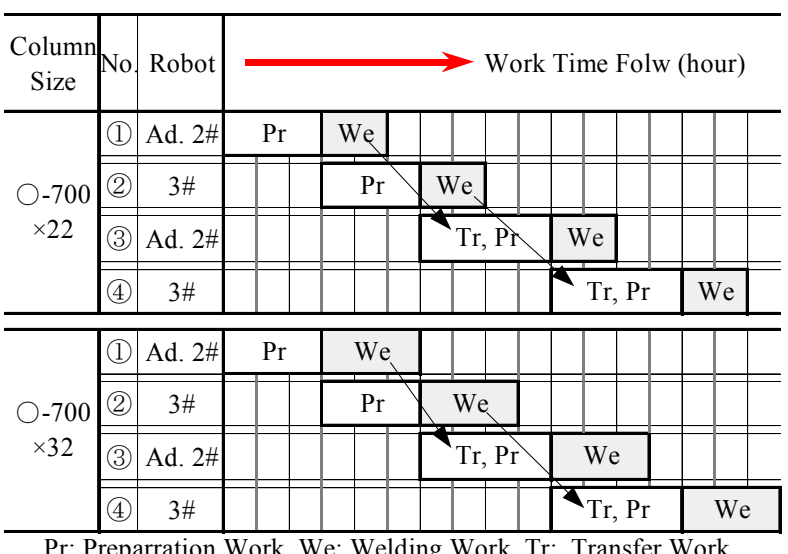

Pr; Preparration Work, We; Welding Work, Tr; Transfer Work

Fig.7 Process of preparation, weld and transfer

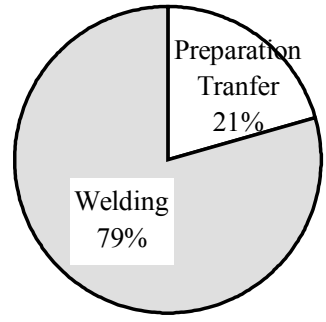

Semi-auto Welding

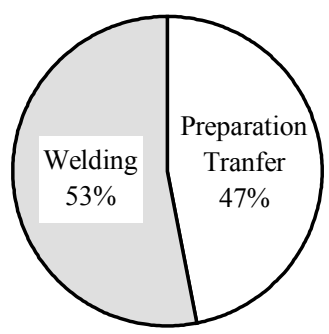

Robot Welding
Fig.8 Time composition of preparation, weld and transfer

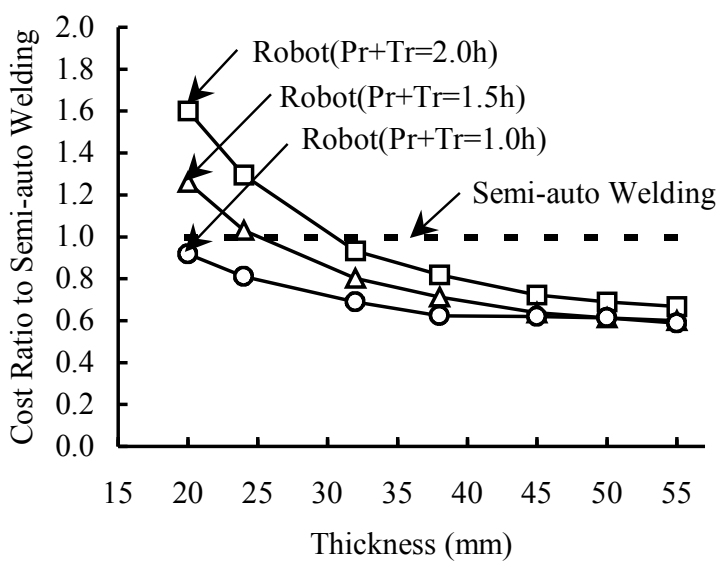

Fig. 9 Decrease ratio of the cost to the thickness

\subsection{Robot Body}

(1) Controller

Although controller of two robots is independently housed in one container, it is needed a new function that controls both robots.

(2) Measuring

Time of measuring takes more than 20 minutes, and is to be shortening. But measuring of column should be eliminated by inputting data of column type, plate thickness and angles of root face.

(3) Down-sizing

The transfer of $3 \#$ robot needs two persons because it is $530 \mathrm{~kg}$ in weight. But downsizing is difficult, because welding equipment are assembled by many kinds of machines, most of which makers are different. However, there are rooms that downsizing should be done, so as for one person to transfer it within the site.

(4) One-touch Joints

There are 10 joints of cables and hoses, and 18 joints of bolts that are used for rails and torches.

All of joints should be simplified one-touch joint or number of them should be lessened.

\subsection{Grove Angle}

Groove angle is $35^{\circ}$ presently, and this angle should be smaller to improve the efficiency of welding work. To achieve this needs a development of cooling torch for a narrow groove.

\subsection{Hire and Cost of Welding equipment}

The use ratio of a welding robot is about $30 \%$ during erection period on site. If the depreciation of the robot includes a period of stand-by, the cost of equipment is high. Therefore it needs rental system to be introduced in near future

There is a dilemma that welding equipment becomes more efficient then cost becomes higher.

\section{CONCLLUSION}

Now we think that welding work is a man-machine system which means cooperation man and robot. But we are aiming at reduction of works by men and increase of works by robots. To achieve this new technologies and site control systems are needed, and understanding and cooperation of interested parties is expected.

On this development procedure, we express our gratitude to the robot-maker Hitachi Zosen LTD, and the steel fabricator Sakamoto Ltd. and Fukuda Kogyou Ltd.

\section{REFERENCES}

[1] K. NISITA "The development of new type column-to-column welding robot at site "THE STRUCTUAL TECHNOGY", Vol. 8 pp. 51-55. 1998.

[2] N. OOKI, etc." APPICATION OF COLUMNFIELD-WELDING ROBOT" AIJ J. TECHNOL Des. No.8.41-46, Jun., 1999. 
[3] K. NISITA etc." Development \& Application of Column-Field-Welding Robot."AIJ, 13th Construction Robot Symposium pp. 45-52. Jan. 2000. 